\title{
Office of Special Populations Research
}

National Cancer Institute

\section{Source}

National Cancer Institute. Office of Special Populations Research. NCI Thesaurus. Code C19206.

The Office of Special Populations Research was established in 1996 to advise the Director of $\mathrm{NCl}$ and provide a focal point for leadership and coordination on minority and other special populations research. 